\title{
Trace elements in glucometabolic disorders: an update
}

Nicolas Wiernsperger ${ }^{1 *}$, JeanRobert Rapin ${ }^{2}$

\begin{abstract}
Many trace elements, among which metals, are indispensable for proper functioning of a myriad of biochemical reactions, more particularly as enzyme cofactors. This is particularly true for the vast set of processes involved in regulation of glucose homeostasis, being it in glucose metabolism itself or in hormonal control, especially insulin. The role and importance of trace elements such as chromium, zinc, selenium, lithium and vanadium are much less evident and subjected to chronic debate. This review updates our actual knowledge concerning these five trace elements. A careful survey of the literature shows that while theoretical postulates from some key roles of these elements had led to real hopes for therapy of insulin resistance and diabetes, the limited experience based on available data indicates that beneficial effects and use of most of them are subjected to caution, given the narrow window between safe and unsafe doses. Clear therapeutic benefit in these pathologies is presently doubtful but some data indicate that these metals may have a clinical interest in patients presenting deficiencies in individual metal levels. The same holds true for an association of some trace elements such as chromium or zinc with oral antidiabetics. However, this area is essentially unexplored in adequate clinical trials, which are worth being performed.
\end{abstract}

\section{Introduction}

Many trace elements, among which metals, involved as cofactors in myriads of biochemical-especially-enzymatic reactions. As such they play cardinal roles in many physiological processes, in particular immunity and metabolism. A good example to illustrate their important contribution is magnesium: low magnesium levels have been associated with increased type 2 diabetes [1,2], whereas controversy exists about the importance of hypomagnesaemia in prediabetic states [3].

Trace elements have been identified for long time as potential candidates for improving metabolic disorders like prediabetes [insulin resistance, obesity, metabolic syndrome] or diabetes. In parallel with increasing comprehension of cellular and biochemical mechanisms leading to-or aggravating- these metabolic disorders, identifying the cellular targets and sites of action of trace elements has reactivated interest in their therapeutic potential. Activation of insulin receptor signalling (chromium), antioxidant properties (selenium, zinc) or inhibition of phosphatases (vanadium) thus appeared

\footnotetext{
* Correspondence: nicolas.wiernsperger@free.fr

'INSERM U870, INSA Lyon, 6 Bld J. Capelle, F-69621 Villeurbanne (France Full list of author information is available at the end of the article
}

promising in view of the key importance of these processes in glucose homeostasis and insulin sensitivity. Indeed insulin receptor/postreceptor signalling defects are considered to underlie glycemic dysregulation and insulin resistance, although the precise causal defects must still be unravelled $[4,5]$. Prediabetic states, and even more so frank diabetes, are characterized by inflammation [cytokines] and oxidative stress, due to disruption of the equilibrium between production of free radicals and their scavenging by multiple antioxidant systems [6-8]. Moreover, these mechanisms may be involved in concert in the pathogenesis of insulin resistance and accompanying pathologies [9].

The present review updates our actual state of knowledge about those five trace elements (chromium, zinc, selenium, vanadium, lithium)which have a therapeutic potential in insulin resistance and diabetes, describing their mechanisms of action and their efficacy in both animal and human investigations.

\section{Chromium}

\section{General aspects}

The importance of chromium $(\mathrm{Cr})$ for glucose metabolic regulation has been seen in clinical states of relatively

\section{Biomed Central}


severe $\mathrm{Cr}$ deficiency, characterized by impaired glucose tolerance, fasting hyperglycaemia and eventually lipid disorders $[10,11]$. Severe deficiencies are mostly limited to parenteral nutrition but analysis of diet plans currently in use in United States reveals a lack of $\mathrm{Cr}$ in many diets, potentially linked to various chronic diseases [12]. The safe and adequate daily intake of $\mathrm{Cr}$ was considered to be in the range 50-200 mg. However, now $30 \mathrm{mg} / \mathrm{d}$ seems a newly admitted value. $\mathrm{Cr}$ is found in relatively high amounts in barley [13]. Cr is poorly absorbed and only toxic in high doses, depending on the milieu, the tissues and the valence of the metal: hexavalent $\mathrm{Cr}$ is highly toxic whereas the in vivo toxicity of trivalent $\mathrm{Cr}$ is debated $[10,14]$. After a period of intense utilization, $\mathrm{Cr}$ seems to be less popular nowadays, as recently reviewed [15]. Studies performed over the last 20 years in both animals and humans have been largely criticized and whether $\mathrm{Cr}$ is indeed an essential element has been questioned $[15,16]$.

$\mathrm{Cr}$ has no effect in healthy individuals and, because these are not Cr-deficient, there is no need for supplementation. $\mathrm{Cr}$ has been administered and tested in various forms such as $\mathrm{Cr}$-chloride, $\mathrm{Cr}$-nicotinate, $\mathrm{Cr}$-proprionate, $\mathrm{Cr}$-histidinate or $\mathrm{Cr}$-picolinate, the latter being by far the best investigated form because of its solubility in water at neutral $\mathrm{pH}$. However in acidic milieu it hydrolyzes and it has been shown that only about $1 \%$ of absorbed $\mathrm{Cr}$ is found in the bloodstream [15]. Most of the studies published about biological effects of $\mathrm{Cr}$ have indeed used Cr-picolinate. Recently new forms aimed at improving $\mathrm{Cr}$ bioavailability have been investigated: a complex of $\mathrm{Cr}$ and D-phenylalanine [17], Cr-dinicocysteinate [18] and a combination of $\mathrm{Cr}$ and biotin [19].

\section{Mechanisms of action}

Several mechanistic studies showed improvements in insulin receptor/postreceptor signalling, leading to increased glucose transport by enhanced activity of the hormone-sensitive GLUT-4 transporters. These effects can be due to the receptor itself, its control mechanisms or its immediate environment in the cell membrane. Crpicolinate was shown to induce various effects: increase in AMPKinase and p38 MAPkinase activities [20], increase in receptor phosphorylation [21] and increase in insulin receptor mRNA (in addition to mRNA for GLUT-4, glycogen synthase and UCP3) [22]. Increased synthesis of IGF receptors, able to functionally replace failing insulin receptors, was also described [23]. Changes in the environment of insulin receptors were shown as reductions in plasma membrane cholesterol $[24,25]$, leading to improved cytoskeletal functioning and enhanced insulin sensitivity. Decreases in TNFa [26,27], resistin [28], interleukin-6, CRP [27] as well as increases in vitamin $\mathrm{C}$ or adiponectin [29] were all positive mechanisms to reduce insulin resistance by $\mathrm{Cr}$.

Finally, one should mention that $\mathrm{Cr}$ can bind directly to insulin, in particular to insulin dimers [30], thereby possibly stabilizing the hormone structure and/or modifying its receptor binding. Interestingly the $\mathrm{Cr}$ binding to insulin receptors occurs on a sequence of 3 aminoacids which are identical to those described for GTF decades ago (see below).

\section{Biological effects}

The appearance of glucose intolerance or even fasting hyperglycaemia in demonstrated cases of $\mathrm{Cr}$ deficiency have rapidly led to investigations on the potential of $\mathrm{Cr}$ supplementation in insulin resistance and diabetes. Furthermore, diabetic patients have about $1 / 3$ less $\mathrm{Cr}$ in various biological samples [31-33]. The reasons for this have recently been discussed [15]. While it was shown that inorganic $\mathrm{Cr}$ was poorly active, Mertz and coworkers identified as early as 1955 a complex found in brewer's yeast, liver and kidney which was able to stimulate glucose transport in the presence-but not in absence- of insulin and which contained $\mathrm{Cr}$. They termed it GTF [glucose tolerance factor]. Its activity required insulin and was dependent on its $\mathrm{Cr}$ content, ideally 4 ions/molecule, while 8 ions/molecule revealed toxic $[34,35]$. GTF (MW about 1500) appeared to be a mixture of $\mathrm{Cr}$, nicotinic acid and the 3 aminoacids constitutive of glutathione [36]. Replacement of $\mathrm{Cr}$ by other metals did not reproduce GTF biological activity. It increased insulin efficacy in adipocytes [35,37] at relatively high concentrations but no effects was found in diabetic patients despite demonstrable increases in $\mathrm{Cr}$ content of various tissues [38]. Presently the GTF story is highly criticized because of missing informations and doubtful technical purification procedures [15]. The GTF story continued with description of a similar structure termed LMWCr.

As for many therapeutic trials, concern must be raised as to the concentrations used. Especially in vitro and in animals studies are usually performed with irrelevant concentrations of the active compound, leading to socalled "pharmacological" effects. Accordingly these data should be viewed with appropriate caution. In vitro many beneficial effects of $\mathrm{Cr}$ salts have been reported for insulin resistance or diabetes; $\mathrm{Cr}$ chloride increased glucose transport in fat and muscle cells as well as in cardiomyocytes $[17,25,35]$. This was partly explained by higher translocation of Glut-4 transporters [20]. It also decreased oxidative stress, glycosylation and lipid peroxidation in erythrocytes and monocytes under hyperglycaemic conditions [26,39-42].

In animals $\mathrm{Cr}$-picolinate reduced AUC for glucose in type1 diabetic rats [37]. Insulin resistance improved in 
high fat/low $\mathrm{Cr}$ diet-fed rats [43], in sucrose-fed rats [44], in Zucker diabetic fatty rats [29], in GK rats $[45,46]$, in JCR-LA corpulent rats [47] and in $\mathrm{db} / \mathrm{db}$ mice [48]. A study in obese Zucker rats failed to report improvements [49].

In addition to positive effects on glucose and insulin metabolic profiles, some studies also reported reduction in triglycerides [37] and stimulation of $\beta$-oxidation [50].

In contrast to animal studies, human studies look much more controversial. This may be due to large differences in $\mathrm{Cr}$ administration protocols. Positive reports with $\mathrm{Cr}$ exist in type2 diabetics treated with sulfonylureas [51] or in combination with either biotin [52] or vitamins $C$ and $E$ [53]. Many human studies failed to see improvements in diabetes, as evidenced by reviews and meta-analyses [54-56]. It is likely that patient selection is cardinal [57] and that $\mathrm{Cr}$ supplementation is primarily of interest in patients suffering from clearcut $\mathrm{Cr}$ deficiency if the aim is to reduce hyperglycaemia [58] or as an adjuvant to already-existing treatment with oral antidiabetics. Changes in blood lipids in humans were not conclusive.

Based on mechanistic hypotheses (see below) the best application might be insulin resistance (prediabetes, metabolic syndrome), although this is also controversial: reduction in insulin resistance was observed in diabetics $[53,59]$ but also in obese women suffering polycystic ovary syndrome [60]. Another study in metabolic syndrome found no effect, however [61].

\section{Zinc}

\section{General aspects}

Zinc $(\mathrm{Zn})$ is an essential micronutrient which has an important role in the functioning of hundreds of enzymes [62], in insulin metabolism and acts as an efficient antioxidant $[63,64]$. Consequently many observations relate to $\mathrm{Zn}$ deficiency, although clinical signs of deficiency are quite modest. $\mathrm{Zn}$ is found mainly in cereals, meat, seafood and dairy products [65]. Although usual intakes of $\mathrm{Zn}$ are harmless, the range between safe and unsafe is relatively narrow [66]. Because $\mathrm{Zn}$ has no storage form, there is need for a constant supply and $\mathrm{Zn}$ availability to cells is particularly well regulated, albeit poorly understood $[67,68]$. $\mathrm{Zn}$ absorption can be reduced by iron or inflammatory bowel diseases. It is transported across cell membranes via two families of transporters: ZnT which stimulate $\mathrm{Zn}$ efflux and Zip which stimulate its influx [69]. Over 20 transporters are identified and most are intracellular [70]. The implication and regulation of $\mathrm{Zn}$ transporters in chronic diseases has been reviewed [71,72]. Concerning metabolic diseases (insulin resistance, metabolic syndrome, diabetes), $\mathrm{Zn}$ is considered important mainly because 1 ) it plays a major role in the stabilization of insulin hexamers and the pancreatic storage of the hormone [73] and 2) it is an efficient antioxidant [74], while oxidative stress is considered to be a main component in initiation and progression of insulin resistance and diabetes $[7,75]$.

Severe $\mathrm{Zn}$ deficiency is not frequent but concerns have nevertheless been raised about $\mathrm{Zn}$ levels in diabetic patients because of increased excretion due to polyuria. Whereas some studies have reported $\mathrm{Zn}$ deficiency in type 2 diabetes [31,76-78], others failed to find significant differences with healthy subjects $[79,80]$. In type 1 diabetes, $\mathrm{Zn}$ deficiency is expected to increase the pancreatic damage [81]. A recent report described reduced levels of $\mathrm{Zn}$ in obese, insulin resistant subjects [82]. Lower $\mathrm{Zn}$ plasma concentrations were found in type 2 diabetics but they were not related to glycemic status or diabetes duration or components of the metabolic syndrome [83]. Interestingly it was reported that diabetic have elevated levels of copper $[78,80]$ and it could be that copper is in fact linked to metabolic syndrome and diabetes [80,84]. Nevertheless, reduced $\mathrm{Zn}$ levels in diabetics appear to be related to increased risk for coronary artery disease [77] and mortality [85].

\section{Mechanisms of action}

Several modes of action have been described to explain the improved action of insulin by $\mathrm{Zn}$. It appears that Zn can have direct insulin-like effects, which may be due to inhibition of the important glycogen-regulating enzyme GSK3 [86]. Other mechanisms include stimulation of the postreceptor proteins Akt and PI3-kinase. $\mathrm{Zn}$ can also reduce cytokines such as IL-1 $\beta$ as well as $\mathrm{NF} \kappa \mathrm{B}[87,88]$. Zn induces metallothionein synthesis, whereby Zn may have indirect efficacy [87]. Finally it has been suggested that the important $\mathrm{Zn}$ concentrations for its action are the intracellular -rather than plasma- levels [89].

$\mathrm{Zn}$ is a remarkable antioxidant: it acts at specific sites where it can compete for iron and copper; it further binds to $\mathrm{SH}$ groups in proteins, protecting them from oxidation [90]. Because $\mathrm{Zn}$ controls metallothionein expression it is involved in cellular redox regulation [91,92]. Oxidative stress can be corrected by dietary $\mathrm{Zn}$ as demonstrated by an elevation of hepatic antioxidant enzymes [93]. In contrast, a recent study showed that in vitro even micromolar concentrations were cytotoxic under prevailing $\mathrm{H} 2 \mathrm{O} 2$-induced oxidative stress [94]. The latter finding is in line with many observations on prooxidant potential of antioxidants, according to doses and present situation $[95,96]$.

\section{Biological effects}

Despite the potential interest in $\mathrm{Zn}$ in diabetes only some investigations have been published (reviewed in 62). 
However the conclusions are far from clear. In animals $\mathrm{Zn}$ prevented the development of type 1 diabetes induced by alloxan or streptozotocin [87]. In a study on $\mathrm{Zn}$ restriction during pregnancy in rats, offsprings presented reduced body weight, increased fat mass and low lean mass and showed reduced insulin response to glucose challenge. Zn supplementation corrected the situation only in females [97]. In db/db mice $\mathrm{Zn}$ reduced hyperglycaemia and hyperinsulinaemia [98]. Administration of $\mathrm{Zn}$ for 3 months reduced proteinuria [99]. Zn restriction increased oxidative stress and the levels of isoprostanes [100], in line with antioxidant effects of Zn. Excessive Zn, on the other hand, increased metabolic syndrome in rats fed a high fat/sucrose diet [101]; this could be reversed by copper and magnesium-enriched poultry egg [102].

High $\mathrm{Zn}$ slightly reduced the risk for type 2 diabetes in a prospective study performed in 8300 women and the effect was limited to the Zn-deficient subgroup [103]. Another study, however, reported aggravation of glucose intolerance in $\mathrm{Zn}$-deficient diabetic patients [104]. In microalbuminuric type 2 diabetic patients $\mathrm{Zn}$ lowered homocysteine levels while increasing vitamin B12 and folate levels [105]. In obese, non-diabetic subjects insulin sensitivity was improved without changes in leptin levels [106]. However no preventive effect against diabetes development could be found in obese women [107]. Oxidative stress was reduced by $\mathrm{Zn}$ in healthy elderly subjects [108].

Some particular forms of $\mathrm{Zn}$ have been tested recently. $\mathrm{Zn}-\alpha 2$-glycoprotein [ZAG] is an adipokine which stimulates energy expenditure in skeletal muscle and brown adipose tissue, resulting in reductions in body weight, glycaemia, triglycerides and NEFAs as found in ob/ob mice. It increases the pancreatic insulin content and improves the glucose tolerance test [109]. Its levels are lower in obese human subcutaneous and visceral adipose tissue and liver, but interestingly does not appear to be related to insulin resistance [110].

$\mathrm{Zn}$-dithiocarbamate and a complex of $\mathrm{Zn}$ with garlicoriginated allixin improved diabetes in KK mice $[111,112]$.

\section{Selenium}

\section{General aspects}

Selenium (Se) is relatively well absorbed from diet, better so if it is in an organic form [113]. It acts as an antioxidant in the form of selenoproteins which contain selenocysteins [114]. About 10 different selenoproteins are described, the best known being glutathione peroxidases, thioredoxin reductases and iodothyronine deiodinases [115]. Selenoproteins are also responsible for the transport of Se to tissues [116,117]. Severe Se deficiency is rare, while reduced Se levels are seen in diabetics together with increased oxidative stress. In offsprings of diabetic patients Se correlates inversely with CRP and with insulin resistance if Se levels are below $80 \mu \mathrm{g} / \mathrm{l}$ [118]. Excess of Se results in excessive oxidative stress and inflammation as well as diseases like idiopathic scoliosis in adolescents [119] or amyotrophic lateral sclerosis [120]. Presently a lively debate exists as to the benefit of supranutritional doses of Se in cancer [121].

\section{Biological effects}

In view of the potent antioxidant $[122,123]$ and antiinflammatory effects of Se and the prominent role played by these disorders in insulin resistance and diabetes, supplementation with $\mathrm{Se}$ in such diseases appears worthwhile. Interestingly there are only few studies available.

In vitro Se inhibited hyperglycaemia or hyperinsulinaemia-induced expression of adhesion molecules via reduction in p38MAPkinase [124]. It also reduced $\mathrm{NF} \kappa \mathrm{B}$, thereby reducing inflammation, CRP and soluble L-selectin [125].

In type 1 diabetic rats $\mathrm{Na}$-selenite protected mitochondria from oxidative stress [126]. Another study showed a better effect with Se-methionine than with Na-selenate [127], confirming other data [128]. In db/db mice selenate reduced gluconeogenesis and inhibited phosphotyrosine phosphatases by $50 \%$ [129]. This effect was attributed to formation of selenite from selenate.

In humans lower levels of sialic acid and triglycerides were reported in young adults having the highest dietary Se intake [130]. Reduction in complement factor 3 [C3] where also reported, which may be beneficial considering the link between C3 and body mass index, skin thickness and triglycerides [131]. However no positive effect was found on diabetes prevention and some data even pointed towards an increased risk [132]. A crosssectional study in almost 9000 american adults as well as another analysis reported a positive link between high Se levels and diabetes $[133,134]$. Therefore, as is the case for use of high Se in cancer [135], caution applies to utilization of Se supplementation in diabetes, especially since quite high doses are required to observe beneficial effects [113,129].

\section{Vanadium}

\section{General aspects}

Vanadium (Va) has been known for about one century to possess antidiabetic properties [136]. However only over the past 2 decades have concrete therapeutic applications been performed. In humans it is uncertain whether $\mathrm{Va}$ is an essential element and it is poorly absorbed in its inorganic form. In vivo $\mathrm{Va}$ is transformed into vanadyl cations via glutathione and complexes with ferritin and transferrin [137]. Indeed Va is known to accumulate in some tissues and concerns 
about its safety have been raised. Bones, liver, kidney lesions as well as loss of weight and gastrointestinal discomfort are well described side-effects of $\mathrm{Va}$, in particular with inorganic Va, whereas organic Va complexes appear more safe $[137,138]$. Recent reports on Va toxicity show mitochondrial lesions, manifested as swelling and opening of the membrane transition pore due to oxidative stress [139]. Lung cancer in mice is another recently described complication with Va pentoxide [140].

\section{Mechanisms of action}

Va is usually described as "insulin mimetic", in view of several in vitro experiments looking at insulin receptor signaling. The most evident mechanisms is an inhibition of phosphotyrosine phosphatases, leading to increased phosphorylation of IRS-1, PKB, GSK3 and FOXO1 [141,142]. Inhibition of phosphatases is supposed to result from production of peroxyvanadate [137]. Restoration of glucokinase activity was reported in the liver of Va-treated diabetic rats [143]. An ex vivo study in Va-treated gerbils suggested that Va was potentiating, rather than mimicking, insulin and that the main action was on GLUT-4 trafficking [144]. This could explain its poor effects in insulin resistant, normoglycaemic states $[145,146]$.

\section{Biological effects}

In animals; many positive reports exist showing beneficial effects of various Va salts in mild or severe diabetes. For example, Va sulphate or more elaborated organic complexes such as bis(maltolato)oxovanadium [BMOV] have proven efficacy in both type 1 and type 2 models $[144,147]$. More recently arylalkylamine derivatives reduced glycaemia in various models, alone [148] or in combination (as low doses) with substrates of semicarbazide-sensitive aminooxidase SSAO [149].

In humans many trials were performed. However, as exposed in a review [150], almost all these trials were short-term and included few patients. Glycaemiareducing activity was seen at doses of $100 \mathrm{mg} / \mathrm{d}$ or more [145,151-153]. No efficacy was found, however, in obese non diabetic subjects [145] or in patients with impaired glucose tolerance [146]. Improvements in insulin-sensitivity were claimed to be due to a hepatic effect rather than to an improvement in peripheral insulin resistance [154]. Recently the newer derivatives $\mathrm{BEOV}$ and BMOV have entered clinical phase II investigations [155].

\section{Lithium}

\section{General aspects}

Lithium (Li) is a complex trace element mainly used in neurological disorders and more particularly for treating mood and bipolar disorders. Its clinical management is difficult and Li is likely toxic $[156,157]$.

\section{Mechanisms of action}

The interest in Li is based on its ability to inhibit GSK3 $[158,159]$, a key enzyme regulating tissue glycogen levels $[160,161]$. Glycogen metabolism, on the other hand, is a particularly important component of glucose homeostasis [162]. GSK3 is now also claimed to be involved in bipolar disorders [163]. Very interestingly the prevalence of metabolic dysregulation and diabetes is highly augmented in bipolar disorders $[164,165]$. Transient diabetes has been associated with $\mathrm{Li}$ withdrawal, pointing to the potential effect of this trace element [166].

\section{Biological effects}

In vitro $\mathrm{Li}$ increased both basal and insulin-stimulated glucose transport, as well as glycogen synthesis in soleus muscle of insulin resistant, obese Zucker rats [167]. The effect operated via increasing p38MAPKinase, confirming previous similar findings [168].

In vivo Li paradoxically increased glycaemia when administered intravenously to diabetic rats, as shown by increases in glucagon [169]. Another study showed paradoxical effects of oral $\mathrm{Li}$ in rat liver: while glycogen synthase was activated and glycogen phosphorylase was decreased, liver glycogen nevertheless decreased [170].

Altogether these data do not support the use of lithium in diabetes despite a cellular target (GSK3) which is potentially of particular interest.

\section{Conclusion}

As a whole, this review shows that trace element supplementation as monotherapy is of weak efficacy in diabetes and hardly efficacious in prediabetic states. The global outcome in humans is somewhat frustrating in view of the logical good expectations from mechanistic effects of these metals at key steps of glucose and insulin regulatory control [171]. As such, these data nicely illustrate a classical observation, i.e. that caution should be given to extrapolations from in vitro or animal data to real human pathology: the data indeed reveal a clear discrepancy between both types of studies. There is little doubt that at least one should 1) better define adequate oral doses and 2) that patient selection should be much more severe. From existing data it appears that in prediabetic or diabetes, trace elements have no or little beneficial effect if the patients do not present deficiencies. It should be stressed out that for all these metals organic derivatives yielded much better results than inorganic forms, likely because of better absorption. Furthermore they could even induce aggravation of metabolic disorders, in line with known inversions of effects of antioxidants at supraphysiological doses. Alternatively the positive effects of micronutrient supplementation is only observed on surrogate parameters such as blood levels of mediators of inflammation and oxidative 
stress or indices of insulin sensitivity without accompanying improvement in glycaemic control. Another concern is the relatively narrow range between safe and unsafe doses for oral treatment of human individuals.

Although surprisingly few data are available, our belief is that trace elements are of benefit in certain conditions: individual reports indeed suggest that they are of value in situations of trace element deficiency and possibly also in combination with either other trace elements or antioxidants or oral antidiabetics [172,173]. In a model of moderate type 2 diabetes, we found that chronic treatment for 2 weeks using an association of $\mathrm{Zn}$ with metformin reduced fasting glycaemia by $30 \%$ over metformin alone, while $\mathrm{Zn}$ alone was without effect (Rapin and Wiernsperger, unpublished data). Finally trace elements may also be of particular interest in pre/postnatal periods since deficiencies during pregnancy have negative consequences on several constitutive and metabolic parameters: in rat offsprings chromium restriction of mothers during pregnancy resulted in increased visceral adiposity [174], reduced skeletal muscle development and increased basal glucose uptake [175]. Use of a mineral-restricted diet in female weanling rats for 12 weeks resulted in increased body fat and triacylglycerol in offsprings [176].

\section{Author details}

${ }^{1}$ INSERM U870, INSA Lyon, 6 Bld J. Capelle, F-69621 Villeurbanne (France. ${ }^{2}$ Faculté de Médecine/Pharmacie, Université de Bourgogne, 3 Bld jeanne d'Arc, F-21000 Dijon (France.

\section{Authors' contributions}

NW wrote the manuscript and performed the literature review. JR revised the manuscript and made modifications of intellectual content. Both authors read and approved the final manuscript.

\section{Competing interests}

The authors declare that they have no competing interests.

Received: 2 November 2010 Accepted: 19 December 2010

Published: 19 December 2010

\section{References}

1. Chaudhary DP, Sharma R, Bansal DD: Implications of magnesium deficiency in type 2 diabetes: a review. Biol Trace Elem Res 2010, 134:119-129.

2. Wells IC: Evidence that the etiology of the syndrome containing type 2 diabetes mellitus results from abnormal magnesium metabolism. Can $\mathrm{J}$ Physiol Pharmacol 2008, 86:16-24

3. Evangelopoulos AA, Vallianou NG, Panagiotakos DB, Georgiou A, Zacharias GA, Alevra AN, et al: An inverse relationship between cumulating components of the metabolic syndrome and serum magnesium levels. Nutr Res 2008, 28:659-663.

4. Abdul-Ghani MA, DeFronzo RA: Pathogenesis of insulin resistance in skeletal muscle. J Biomed Biotechnol 2010, 476279.

5. Henriksen EJ: Dysregulation of Glycogen Synthase Kinase-3 in Skeletal Muscle and the Etiology of Insulin Resistance and Type 2 Diabetes. Curr Diabetes Rev 2010, 6:285-293.

6. Friederich M, Hansell P, Palm F: Diabetes, oxidative stress, nitric oxide and mitochondria function. Curr Diabetes Rev 2009, 5:120-144.

7. Kaneto $H$, Katakami $N$, Matsuhisa M, Matsuoka TA: Role of reactive oxygen species in the progression of type 2 diabetes and atherosclerosis. Mediators Inflamm 2010, 453892.
8. Zeyda M, Stulnig TM: Obesity, inflammation, and insulin resistance-a mini-review. Gerontology 2009, 55:379-386.

9. Cheng Z, Tseng Y, White MF: Insulin signaling meets mitochondria in metabolism. Trends Endocrinol Metab 2010, 21:589-598.

10. Goldhaber SB: Trace element risk assessment: essentiality vs toxicity. Regul Toxicol Pharmacol 2003, 38:232-242.

11. Wallach S: Clinical and biochemical aspects of chromium deficiency. J Am Coll Nutr 1985, 4:107-120.

12. Calton JB: Prevalence of micronutrient deficiency in popular diet plans. J Int Soc Sports Nutr 2010, 7:24.

13. Mahdi GS: Barley as high-chromium food. J Am Diet Assoc 1995, 95:749.

14. Levina A, Lay PA: Chemical properties and toxicity of chromium[III] nutritional supplements. Chem Res Toxicol 2008, 21:563-571.

15. Vincent JB: Chromium: celebrating 50 years as an essential element? Dalton Trans 2010, 39:3787-3794.

16. Stallings DM, Hepburn DD, Hannah M, Vincent JB, O'Donnell J: Nutritional supplement chromium picolinate generates chromosomal aberrations and impedes progeny development in Drosophila melanogaster. Mutat Res 2006, 610:101-113.

17. Zhao P, Wang J, Ma H, Xiao Y, He L, Tong C, et al: A newly synthetic chromium complex-chromium [D-phenylalanine]3 activates AMPactivated protein kinase and stimulates glucose transport. Biochem Pharmacol 2009, 77:1002-1010.

18. Sreejayan N, Marone PA, Lau FC, Yasmin T, Bagchi M, Bagchi D: Safety and toxicological evaluation of a novel chromium[III] dinicocysteinate complex. Toxicol Mech Methods 2010, 20:321-333.

19. Fuhr JP Jr, He H, Goldfarb N, Nash DB: Use of chromium picolinate and biotin in the management of type 2 diabetes: an economic analysis. Dis Manag 2005, 8:265-275.

20. Wang YQ, Yao MH: Effects of chromium picolinate on glucose uptake in insulin-resistant 3T3-L1 adipocytes involve activation of p38 MAPK. J Nutr Biochem 2009, 20:982-991.

21. Wang $H$, Kruszewski A, Brautigan DL: Cellular chromium enhances activation of insulin receptor kinase. Biochemistry 2005, 44:8167-8175.

22. Qiao W, Peng Z, Wang Z, Wei J, Zhou A: Chromium improves glucose uptake and metabolism through upregulating the mRNA levels of IR, GLUT4, GS, and UCP3 in skeletal muscle cells. Biol Trace Elem Res 2009, 131:133-142.

23. Peng Z, Qiao W, Wang Z, Dai Q, He J, Guo C, et al: Chromium Improves Protein Deposition Through Regulating the mRNA Levels of IGF-1, IGF-1R, and Ub in Rat Skeletal Muscle Cells. Biol Trace Elem Res 2010, 137:226-234.

24. Horvath EM, Tackett L, McCarthy AM, Raman P, Brozinick JT, Elmendorf JS: Antidiabetogenic effects of chromium mitigate hyperinsulinemiainduced cellular insulin resistance via correction of plasma membrane cholesterol imbalance. Mol Endocrinol 2008, 22:937-950.

25. Pattar GR, Tackett L, Liu P, Elmendorf JS: Chromium picolinate positively influences the glucose transporter system via affecting cholesterol homeostasis in adipocytes cultured under hyperglycemic diabetic conditions. Mutat Res 2006, 610:93-100.

26. Jain SK, Kannan K: Chromium chloride inhibits oxidative stress and TNF-alpha secretion caused by exposure to high glucose in cultured U937 monocytes. Biochem Biophys Res Commun 2001, 289:687-691.

27. Jain SK, Rains $J L$, Croad JL: Effect of chromium niacinate and chromium picolinate supplementation on lipid peroxidation, TNF-alpha, IL-6, CRP, glycated hemoglobin, triglycerides, and cholesterol levels in blood of streptozotocin-treated diabetic rats. Free Radic Biol Med 2007, 43:1124-1131.

28. Wang $Y Q$, Dong $Y$, Yao $M H$ : Chromium picolinate inhibits resistin secretion in insulin-resistant 3T3-L1 adipocytes via activation of ampactivated protein kinase. Clin Exp Pharmacol Physiol 2009, 36:843-849.

29. Jain SK, Croad JL, Velusamy T, Rains $J$, Bull R: Chromium dinicocysteinate supplementation can lower blood glucose, CRP, MCP-1, ICAM-1, creatinine, apparently mediated by elevated blood vitamin $C$ and adiponectin and inhibition of NFkappaB, Akt, and Glut-2 in livers of zucker diabetic fatty rats. Mol Nutr Food Res 2010, 54:1371-1380.

30. Sreekanth R, Pattabhi V, Rajan SS: Molecular basis of chromium insulin interactions. Biochem Biophys Res Commun 2008, 369:725-729.

31. Kazi TG, Afridi HI, Kazi N, Jamali MK, Arain MB, Jalbani N, et al: Copper, chromium, manganese, iron, nickel, and zinc levels in biological samples of diabetes mellitus patients. Biol Trace Elem Res 2008, 122:1-18. 
32. Kraszeski JL, Wallach S, Verch RL: Effect of insulin on radiochromium distribution in diabetic rats. Endocrinology 1979, 104:881-885.

33. Morris BW, MacNeil S, Hardisty CA, Heller S, Burgin C, Gray TA: Chromium homeostasis in patients with type II [NIDDM] diabetes. $J$ Trace Elem Med Biol 1999, 13:57-61.

34. Davis CM, Vincent JB: Chromium oligopeptide activates insulin receptor tyrosine kinase activity. Biochemistry 1997, 36:4382-4385.

35. Yamamoto A, Wada O, Ono T: Isolation of a biologically active lowmolecular-mass chromium compound from rabbit liver. Eur J Biochem 1987, 65:627-631.

36. Mertz W: Chromium in human nutrition: a review. J Nutr 1993, 123:626-633.

37. Shindea UA, Sharma G, Xu YJ, Dhalla NS, Goyal RK: Insulin sensitising action of chromium picolinate in various experimental models of diabetes mellitus. J Trace Elem Med Biol 2004, 18:23-32.

38. Rabinowitz MB, Gonick HC, Levin SR, Davidson MB: Effects of chromium and yeast supplements on carbohydrate and lipid metabolism in diabetic men. Diabetes Care 1983, 6:319-327.

39. Dogukan A, Tuzcu M, Juturu V, Cikim G, Ozercan I, Komorowski J, et al: Effects of chromium histidinate on renal function, oxidative stress, and heat-shock proteins in fat-fed and streptozotocin-treated rats. J Ren Nutr 2010, 20:112-120.

40. Jain SK, Patel P, Rogier K, Jain SK: Trivalent chromium inhibits protein glycosylation and lipid peroxidation in high glucose-treated erythrocytes. Antioxid Redox Signal 2006, 8:238-241.

41. Refaie FM, Esmat AY, Mohamed AF, Aboul Nour WH: Effect of chromium supplementation on the diabetes induced-oxidative stress in liver and brain of adult rats. Biometals 2009 .

42. Yang X, Li SY, Dong F, Ren J, Sreejayan N: Insulin-sensitizing and cholesterol-lowering effects of chromium [D-Phenylalanine]3. J Inorg Biochem 2006, 100:1187-1193.

43. Striffler JS, Polansky MM, Anderson RA: Dietary chromium decreases insulin resistance in rats fed a high-fat, mineral-imbalanced diet. Metabolism 1998, 47:396-400.

44. Dong F, Yang X, Sreejayan N, Ren J: Chromium [D-phenylalanine]3 improves obesity-induced cardiac contractile defect in ob/ob mice. Obesity 2007, 15:2699-2711.

45. Kim DS, Kim TW, Kang JS: Chromium picolinate supplementation improves insulin sensitivity in Goto-Kakizaki diabetic rats. J Trace Elem Med Biol 2004, 17:243-247.

46. Kim DS, Kim TW, Park IK, Kang JS, Om AS: Effects of chromium picolinate supplementation on insulin sensitivity, serum lipids, and body weight in dexamethasone-treated rats. Metabolism 2002, 51:589-594

47. Cefalu WT, Wang ZQ, Zhang XH, Baldor LC, Russell JC: Oral chromium picolinate improves carbohydrate and lipid metabolism and enhances skeletal muscle Glut-4 translocation in obese, hyperinsulinemic [JCR-LA corpulent] rats. J Nutr 2002, 132:1107-1114.

48. Yang X, Li SY, Dong F, Ren J, Sreejayan N: Insulin-sensitizing and cholesterol-lowering effects of chromium [D-Phenylalanine]3. J Inorg Biochem 2006, 100:1187-1193.

49. Mozaffari MS, Abdelsayed R, Liu JY, Wimborne H, El-Remessy A, ElMarakby A: Effects of chromium picolinate on glycemic control and kidney of the obese Zucker rat. Nutr Metab 2009, 6:51.

50. Kuryl T, Krejpcio Z, Wojciak RW, Lipko M, Debski B, Staniek H: Chromium[III] propionate and dietary fructans supplementation stimulate erythrocyte glucose uptake and beta-oxidation in lymphocytes of rats. Biol Trace Elem Res 2006, 114:237-248.

51. Martin J, Wang ZQ, Zhang XH, Wachtel D, Volaufova J, Matthews DE, et al: Chromium picolinate supplementation attenuates body weight gain and increases insulin sensitivity in subjects with type 2 diabetes. Diabetes Care 2006, 29:1826-1832.

52. Singer GM, Geohas J: The effect of chromium picolinate and biotin supplementation on glycemic control in poorly controlled patients with type 2 diabetes mellitus: a placebo-controlled, double-blinded, randomized trial. Diabetes Technol Ther 2006, 8:636-643.

53. Lai MH: Antioxidant effects and insulin resistance improvement of chromium combined with vitamin $\mathrm{C}$ and $\mathrm{E}$ supplementation for type 2 diabetes mellitus. J Clin Biochem Nutr 2008, 43:191-198.

54. Althuis MD, Jordan NE, Ludington EA, Wittes JT: Glucose and insulin responses to dietary chromium supplements: a meta-analysis. Am J Clin Nutr 2002, 76:148-155.
55. Balk EM, Tatsioni A, Lichtenstein AH, Lau J, Pittas AG: Effect of chromium supplementation on glucose metabolism and lipids: a systematic review of randomized controlled trials. Diabetes Care 2007, 30:2154-163.

56. Broadhurst $C L$, Domenico P: Clinical studies on chromium picolinate supplementation in diabetes mellitus-a review. Diabetes Technol Ther 2006, 8:677-687.

57. Wang ZQ, Qin J, Martin J, Zhang XH, Sereda O, Anderson RA, et al: Phenotype of subjects with type 2 diabetes mellitus may determine clinical response to chromium supplementation. Metabolism 2007, 56:1652-1655.

58. Wang ZQ, Cefalu WT: Current concepts about chromium supplementation in type 2 diabetes and insulin resistance. Curr Diab Rep 2010, 10:145-151.

59. Vladeva SV, Terzieva DD, Arabadjiiska DT: Effect of chromium on the insulin resistance in patients with type II diabetes mellitus. Folia Med 2005, 47:59-62

60. Lydic ML, McNurlan M, Bembo S, Mitchell L, Komaroff E, Gelato M: Chromium picolinate improves insulin sensitivity in obese subjects with polycystic ovary syndrome. Fertil Steril 2005, 86:243-246.

61. labal N, Cardillo S, Volger S, Bloedon LT, Anderson RA, Boston R, et al: Chromium picolinate does not improve key features of metabolic syndrome in obese nondiabetic adults. Metab Syndr Relat Disord 2009, 7:143-150.

62. Haase $\mathrm{H}$, Overbeck $\mathrm{S}$, Rink L: Zinc supplementation for the treatment or prevention of disease: current status and future perspectives. Exp Gerontol 2008, 43:394-408.

63. Faure P, Lafond JL, Coudray C, Rossini E, Halimi S, Favier A, et al: Zinc prevents the structural and functional properties of free radical treatedinsulin. Biochim Biophys Acta 1994, 1209:260-264.

64. Saper RB, Rash R: Zinc: an essential micronutrient. Am Fam Physician 2009, 79:768-772.

65. Walsh CT, Sandstead HH, Prasad AS, Newberne PM, Fraker PJ: Zinc: health effects and research priorities for the 1990s. Environ Health Perspect 1994, 102(Suppl 2):5-46.

66. Maret W, Sandstead HH: Zinc requirements and the risks and benefits of zinc supplementation. J Trace Elem Med Biol 2006, 20:3-18.

67. Lowe NM, Fekete K, Decsi T: Methods of assessment of zinc status in humans: a systematic review. Am J Clin Nutr 2009, 89:2040S-2051S.

68. Sekler I, Sensi SL, Hershfinkel M, Silverman WF: Mechanism and regulation of cellular zinc transport. Mol Med 2007, 13:337-343.

69. Liuzzi JP, Cousins RJ: Mammalian zinc transporters. Annu Rev Nutr 2004, 24:151-172.

70. Lichten LA, Cousins RJ: Mammalian zinc transporters: nutritional and physiologic regulation. Annu Rev Nutr 2009, 29:153-176.

71. Devirgiliis C, Zalewski PD, Perozzi G, Murgia C: Zinc fluxes and zinc transporter genes in chronic diseases. Mutat Res 2007, 62:84-93.

72. Rungby J: Zinc, zinc transporters and diabetes. Diabetologia 2010, 53:1549-51.

73. Wijesekara N, Chimienti F, Wheeler MB: Zinc, a regulator of islet function and glucose homeostasis. Diabetes Obes Metab 2009, 11(Suppl 4):202-214.

74. Prasad AS: Clinical, immunological, anti-inflammatory and antioxidant roles of zinc. Exp Gerontol 2008, 43:370-377.

75. Wiernsperger NF: Oxidative stress as a therapeutic target in diabetes: revisiting the controversy. Diabetes Metab 2003, 29:579-585.

76. Afridi HI, Kazi TG, Kazi N, Baig JA, Jamali MK, Arain MB, et al: Status of essential trace metals in biological samples of diabetic mother and their neonates. Arch Gynecol Obstet 2009, 280:415-423.

77. Singh RB, Niaz MA, Rastogi SS, Bajaj S, Gaoli Z, Shoumin Z: Current zinc intake and risk of diabetes and coronary artery disease and factors associated with insulin resistance in rural and urban populations of North India. J Am Coll Nutr 1998, 17:564-570.

78. Viktorinova A, Toserova E, Krizko M, Durackova Z: Altered metabolism of copper, zinc, and magnesium is associated with increased levels of glycated hemoglobin in patients with diabetes mellitus. Metabolism 2009, 58:1477-1482.

79. Serdar MA, Bakir F, Hasimi A, Celik T, Akin O, Kenar L, et al: Trace and toxic element patterns in nonsmoker patients with noninsulin-dependent diabetes mellitus, impaired glucose tolerance, and fasting glucose. Int $J$ Diabetes Dev Ctries 2009, 29:35-40.

80. Zargar AH, Shah NA, Masoodi SR, Laway BA, Dar FA, Khan AR, et al: Copper, zinc, and magnesium levels in non-insulin dependent diabetes mellitus. Postgrad Med J 1998, 74:665-668. 
81. Chausmer AB: Zinc, insulin and diabetes. J Am Coll Nutr 1998, 17:109-115

82. Suliburska J, Bogdanski P, Pupek-Musialik D, Krejpcio Z: Dietary intake and serum and hair concentrations of minerals and their relationship with serum lipids and glucose levels in hypertensive and obese patients with insulin resistance. Biol Trace Elem Res.

83. Obeid O, Elfakhani M, Hlais S, Iskandar M, Batal M, Mouneimne Y, et al: Plasma copper, zinc, and selenium levels and correlates with metabolic syndrome components of lebanese adults. Biol Trace Elem Res 2008, 123:58-65.

84. Aguilar MV, Saavedra P, Arrieta FJ, Mateos CJ, Gonzalez MJ, Meseguer I, et al: Plasma mineral content in type- 2 diabetic patients and their association with the metabolic syndrome. Ann Nutr Metab 2007, 51:402-406

85. Soinio M, Marniemi J, Laakso M, Pyorala K, Lehto S, Ronnemaa T: Serum zinc level and coronary heart disease events in patients with type 2 diabetes. Diabetes Care 2007, 30:523-528.

86. Ilouz R, Kaidanovich O, Gurwitz D, Eldar-Finkelman H: Inhibition of glycogen synthase kinase-3beta by bivalent zinc ions: insight into the insulin-mimetic action of zinc. Biochem Biophys Res Commun 2002, 295:102-106.

87. Jansen J, Karges W, Rink L: Zinc and diabetes-clinical links and molecular mechanisms. J Nutr Biochem 2009, 20:399-417.

88. Prasad AS, Bao B, Beck FW, Kucuk O, Sarkar FH: Antioxidant effect of zinc in humans. Free Radic Biol Med 2004, 37:1182-1190.

89. Mocchegiani E, Giacconi R, Malavolta M: Zinc signalling and subcellular distribution: emerging targets in type 2 diabetes. Trends Mol Med 2008, 14:419-428.

90. Bettger WJ: Zinc and selenium, site-specific versus general antioxidation. Can J Physiol Pharmacol 1993, 71:721-724.

91. Foster M, Samman S: Zinc and redox signaling: perturbations associated with cardiovascular disease and diabetes mellitus. Antioxid Redox Signal 2010, 13:1549-1573.

92. Maret $\mathrm{W}$ : The function of zinc metallothionein: a link between cellular zinc and redox state. J Nutr 2000, 130(5S Suppl):1455S-8S.

93. Tupe RS, Tupe SG, Tarwadi KV, Agte W: Effect of different dietary zinc levels on hepatic antioxidant and micronutrients indices under oxidative stress conditions. Metabolism 2010, 59:1603-1611.

94. Matsui H, Oyama TM, Okano Y, Hashimoto E, Kawanai T, Oyama Y: Low micromolar zinc exerts cytotoxic action under $\mathrm{H}$ [2]O[2]-induced oxidative stress: Excessive increase in intracellular $\mathrm{Zn}[2+]$ concentration. Toxicology 2010, 276:27-32.

95. Steinhubl SR: Why have antioxidants failed in clinical trials? Am J Cardiol 2008, 101:14D-19D.

96. Wiernsperger NF: Oxidative stress: the special case of diabetes. Biofactors 2003, 19:11-18.

97. Padmavathi IJ, Kishore YD, Venu L, Ganeshan M, Harishankar N, Giridharan NV, et al: Prenatal and perinatal zinc restriction: effects on body composition, glucose tolerance and insulin response in rat offspring. Exp Physiol 2009, 94:761-769.

98. Simon SF, Taylor CG: Dietary zinc supplementation attenuates hyperglycemia in db/db mice. Exp Biol Med 2001, 226yang:43-51.

99. Tang Y, Yang Q, Lu J, Zhang X, Suen D, Tan Y, et al: Zinc supplementation partially prevents renal pathological changes in diabetic rats. $J$ Nutr Biochem 2010, 21:237-246.

100. Bruno RS, Song Y, Leonard SW, Mustacich DJ, Taylor AW, Traber MG, et al: Dietary zinc restriction in rats alters antioxidant status and increases plasma F2 isoprostanes. J Nutr Biochem 2007, 18:509-518.

101. Taneja SK, Mandal R, Girhotra S: Long term excessive Zn-supplementation promotes metabolic syndrome-X in Wistar rats fed sucrose and fat rich semisynthetic diet. Indian J Exp Biol 2006, 44:705-718.

102. Taneja SK, Mandal R: Modulation of Zn-induced hyperinsulinemia/insulin resistance in Wistar rat fed modified poultry egg. Biofactors 2009, 35:389-398.

103. Sun Q, van Dam RM, Willett WC, Hu FB: Prospective study of zinc intake and risk of type 2 diabetes in women. Diabetes Care 2009, 32:629-634.

104. Raz I, Karsai D, Katz M: The influence of zinc supplementation on glucose homeostasis in NIDDM. Diabetes Res 1989, 11:73-79.

105. Heidarian E, Amini M, Parham M, Aminorroaya A: Effect of zinc supplementation on serum homocysteine in type 2 diabetic patients with microalbuminuria. Rev Diabet Stud 2009, 6:64-70.
106. Marreiro DN, Geloneze B, Tambascia MA, Lerario AC, Halpern A, Cozzolino SM: Effect of zinc supplementation on serum leptin levels and insulin resistance of obese women. Biol Trace Elem Res 2006, 112:109-118.

107. Beletate V, El Dib RP, Atallah AN: Zinc supplementation for the prevention of type 2 diabetes mellitus. Cochrane Database Syst Rev 2007, CD005525.

108. Mariani E, Mangialasche F, Feliziani FT, Cecchetti R, Malavolta M, Bastiani P, et al: Effects of zinc supplementation on antioxidant enzyme activities in healthy old subjects. Exp Gerontol 2008, 43:445-451.

109. Russell ST, Tisdale MJ: Antidiabetic properties of zinc-alpha2-glycoprotein in ob/ob mice. Endocrinology 2010, 151:948-957.

110. Selva DM, Lecube A, Hernandez C, Baena JA, Fort JM, Simo R: Lower zincalpha2-glycoprotein production by adipose tissue and liver in obese patients unrelated to insulin resistance. J Clin Endocrinol Metab 2009 94:4499-4507.

111. Adachi $Y$, Yoshida J, Kodera $Y$, Kiss T, Jakusch T, Enyedy EA, et al: Oral administration of a zinc complex improves type 2 diabetes and metabolic syndromes. Biochem Biophys Res Commun 2006, 351:165-170

112. Yoshikawa $Y$, Adachi $Y$, Sakurai $H$ : A new type of orally active anti-diabetic Zn[II]-dithiocarbamate complex. Life Sci 2007, 80:759-766.

113. Navarro-Alarcon M, Cabrera-Vique C: Selenium in food and the human body: a review. Sci Total Environ 2008, 400:115-141.

114. Steinbrenner $H$, Sies $H$ : Protection against reactive oxygen species by selenoproteins. Biochim Biophys Acta 2009, 1790:1478-85.

115. Lu J, Holmgren A: Selenoproteins. J Biol Chem 2009, 284:723-727.

116. Burk RF, Hill KE, Motley AK: Selenoprotein metabolism and function: evidence for more than one function for selenoprotein P. J Nutr 2003, 133(5 Suppl 1):1517S-20S.

117. Holben DH, Smith AM: The diverse role of selenium within selenoproteins: a review. J Am Diet Assoc 1999, 99:836-843.

118. Ozkaya M, Sahin M, Cakal E, Gisi K, Bilge F, Kilinc M: Selenium levels in first-degree relatives of diabetic patients. Biol Trace Elem Res 2009, 128:144-151.

119. Yang Z, Xie Y, Chen J, Zhang D, Yang C, Li M: High selenium may be a risk factor of adolescent idiopathic scoliosis. Med Hypotheses 2010 75:126-127.

120. Vinceti M, Maraldi T, Bergomi M, Malagoli C: Risk of chronic low-dose selenium overexposure in humans: insights from epidemiology and biochemistry. Rev Environ Health 2009, 24:231-248.

121. Neve J: Selenium as a 'nutraceutical': how to conciliate physiological and supra-nutritional effects for an essential trace element. Curr Opin Clin Nutr Metab Care 2002, 5:659-663.

122. Battin EE, Brumaghim JL: Antioxidant activity of sulfur and selenium: a review of reactive oxygen species scavenging, glutathione peroxidase, and metal-binding antioxidant mechanisms. Cell Biochem Biophys 2009, 55:1-23.

123. Tapiero H, Townsend DM, Tew KD: The antioxidant role of selenium and seleno-compounds. Biomed Pharmacother 2003, 57:134-144.

124. Zheng HT, Zhou LN, Huang CJ, Hua X, Jian R, Su BH, et al: Selenium inhibits high glucose- and high insulin-induced adhesion molecule expression in vascular endothelial cells. Arch Med Res 2008, 39:373-379.

125. Duntas LH: Selenium and inflammation: underlying anti-inflammatory mechanisms. Horm Metab Res 2009, 41:443-447.

126. Can B, Ulusu NN, Kilinc K, Leyla Acan N, Saran Y, Turan B: Selenium treatment protects diabetes-induced biochemical and ultrastructural alterations in liver tissue. Biol Trace Elem Res 2005, 105:135-150.

127. Erbayraktar Z, Yilmaz O, Artmann AT, Cehreli R, Coker C: Effects of selenium supplementation on antioxidant defense and glucose homeostasis in experimental diabetes mellitus. Biol Trace Elem Res 2007, 118:217-226

128. Schrauzer GN: Nutritional selenium supplements: product types, quality, and safety. J Am Coll Nutr 2001, 20:1-4.

129. Mueller AS, Pallauf J: Compendium of the antidiabetic effects of supranutritional selenate doses. In vivo and in vitro investigations with type II diabetic db/db mice. J Nutr Biochem 2006, 17:548-560.

130. Zulet MA, Puchau B, Hermsdorff HH, Navarro C, Martinez JA: Dietary selenium intake is negatively associated with serum sialic acid and metabolic syndrome features in healthy young adults. Nutr Res 2009, 29:41-48.

131. Puchau B, Zulet MA, Gonzalez de Echavarri A, Navarro-Blasco I, Martinez JA: Selenium intake reduces serum C3, an early marker of metabolic 
syndrome manifestations, in healthy young adults. Eur J Clin Nutr 2009, 63:858-864.

132. Stranges S, Marshall JR, Natarajan R, Donahue RP, Trevisan M, Combs GF, et al: Effects of long-term selenium supplementation on the incidence of type 2 diabetes: a randomized trial. Ann Intern Med 2007, 147:217-223.

133. Bleys J, Navas-Acien A, Guallar E: Serum selenium and diabetes in U.S. adults. Diabetes Care 2007, 30:829-834.

134. Laclaustra M, Navas-Acien A, Stranges S, Ordovas JM, Guallar E: Serum selenium concentrations and hypertension in the US Population. Circ Cardiovasc Qual Outcomes 2009, 2::369-376.

135. Muecke R, Schomburg L, Buentzel J, Kisters K, Micke O: Selenium or no selenium-that is the question in tumor patients: a new controversy. Integr Cancer Ther 2010, 9:136-141.

136. Thompson KH, Orvig C: Vanadium in diabetes: 100 years from Phase 0 to Phase I. J Inorg Biochem 2006, 100:1925-1935.

137. Srivastava AK: Anti-diabetic and toxic effects of vanadium compounds. Mol Cell Biochem 2000, 206:177-182.

138. Domingo JL: Vanadium and tungsten derivatives as antidiabetic agents: a review of their toxic effects. Biol Trace Elem Res 2002, 88:97-112.

139. Zhao Y, Ye L, Liu H, Xia Q, Zhang Y, Yang X, et al: Vanadium compounds induced mitochondria permeability transition pore [PTP] opening related to oxidative stress. J Inorg Biochem 2010, 104:371-378.

140. Assem FL, Levy LS: A review of current toxicological concerns on vanadium pentoxide and other vanadium compounds: gaps in knowledge and directions for future research. J Toxicol Environ Health $B$ Crit Rev 2009, 12:289-306.

141. Mehdi MZ, Pandey SK, Theberge JF, Srivastava AK: Insulin signal mimicry as a mechanism for the insulin-like effects of vanadium. Cell Biochem Biophys 2006, 44:73-81.

142. Vardatsikos G, Mehdi MZ, Srivastava AK: Bis[maltolato]-oxovanadium [IV]induced phosphorylation of PKB, GSK-3 and FOXO1 contributes to its glucoregulatory responses. Int J Mol Med 2009, 24:303-309.

143. Gil J, Miralpeix M, Carreras J, Bartrons R: Insulin-like effects of vanadate on glucokinase activity and fructose 2,6-bisphosphate levels in the liver of diabetic rats. J Biol Chem 1988, 263:1868-1871.

144. Shafrir E, Spielman S, Nachliel I, Khamaisi M, Bar-On H, Ziv E: Treatment of diabetes with vanadium salts: general overview and amelioration of nutritionally induced diabetes in the Psammomys obesus gerbil. Diabetes Metab Res Rev 2001, 17:55-66.

145. Halberstam M, Cohen N, Shlimovich P, Rossetti L, Shamoon H: Oral vanadyl sulfate improves insulin sensitivity in NIDDM but not in obese nondiabetic subjects. Diabetes 1996, 45:659-666.

146. Jacques-Camarena O, Gonzalez-Ortiz M, Martinez-Abundis E, LopezMadrueno JF, Medina-Santillan R: Effect of vanadium on insulin sensitivity in patients with impaired glucose tolerance. Ann Nutr Metab 2008, 53:195-198.

147. Poucheret P, Verma S, Grynpas MD, McNeill JH: Vanadium and diabetes. Mol Cell Biochem 1998, 188:73-80.

148. Garcia-Vicente S, Yraola F, Marti L, Gonzalez-Munoz E, Garcia-Barrado MJ, Canto C, et al: Oral insulin-mimetic compounds that act independently of insulin. Diabetes 2007, 56:486-493.

149. Zorzano A, Palacin M, Marti L, Garcia-Vicente S: Arylalkylamine vanadium salts as new anti-diabetic compounds. J Inorg Biochem 2009, 103:559-566.

150. Smith DM, Pickering RM, Lewith GT: A systematic review of vanadium oral supplements for glycaemic control in type 2 diabetes mellitus. QJM 2008, 101:351-358

151. Boden G, Chen X, Ruiz J, van Rossum GD, Turco S: Effects of vanadyl sulfate on carbohydrate and lipid metabolism in patients with noninsulin-dependent diabetes mellitus. Metabolism 1996, 45:1130-1135.

152. Cohen N, Halberstam M, Shlimovich P, Chang CJ, Shamoon H, Rossetti L: Oral vanadyl sulfate improves hepatic and peripheral insulin sensitivity in patients with non-insulin-dependent diabetes mellitus. J Clin Invest 1995, 95:2501-2509.

153. Goldfine AB, Patti ME, Zuberi L, Goldstein BJ, LeBlanc R, Landaker EJ, et al: Metabolic effects of vanadyl sulfate in humans with non-insulindependent diabetes mellitus: in vivo and in vitro studies. Metabolism 2000, 49:400-410.

154. Cusi K, Cukier S, Defronzo RA, Torres M, Puchulu FM, Redondo JC: Vanadyl sulfate improves hepatic and muscle insulin sensitivity in type 2 diabetes. J Clin Endocrinol Metab 2001, 86:1410-1417.
155. Thompson KH, Lichter J, LeBel C, Scaife MC, McNeill JH, Orvig C: Vanadium treatment of type 2 diabetes: a view to the future. J Inorg Biochem 2009, 103:554-558.

156. Freeman MP, Freeman SA: Lithium: clinical considerations in internal medicine. Am J Med 2006, 119:478-481.

157. Livingstone C, Rampes H: Lithium: a review of its metabolic adverse effects. J Psychopharmacol 2006, 20:347-355.

158. Jope RS: Lithium and GSK-3: one inhibitor, two inhibitory actions, multiple outcomes. Trends Pharmacol Sci 2003, 24:441-443.

159. O'Brien WT, Klein PS: Validating GSK3 as an in vivo target of lithium action. Biochem Soc Trans 2009, 37(Pt 5):1133-1138.

160. Henriksen EJ, Kinnick TR, Teachey MK, O'Keefe MP, Ring D, Johnson KW, et al: Modulation of muscle insulin resistance by selective inhibition of GSK-3 in Zucker diabetic fatty rats. Am J Physiol Endocrinol Metab 2003, 284:E892-E900.

161. Kaidanovich O, Eldar-Finkelman H: The role of glycogen synthase kinase-3 in insulin resistance and type 2 diabetes. Expert Opin Ther Targets 2002, 6:555-561.

162. Hers HG: The control of glycogen metabolism in the liver. Annu Rev Biochem 1976, 45:167-189.

163. Gould TD, Zarate CA, Manji HK: Glycogen synthase kinase-3: a target for novel bipolar disorder treatments. J Clin Psychiatry 2004, 65:10-21.

164. Fiedorowicz JG, Palagummi NM, Forman-Hoffman VL, Miller DD, Haynes WG: Elevated prevalence of obesity, metabolic syndrome, and cardiovascular risk factors in bipolar disorder. Ann Clin Psychiatry 2008, 20:131-137.

165. Sicras A, Rejas J, Navarro R, Serrat J, Blanca M: Metabolic syndrome in bipolar disorder: a cross-sectional assessment of a Health Management Organization database. Bipolar Disord 2008, 10:607-616.

166. Okosieme OE, Campbell A, Patton K, Evans ML: Transient diabetes associated with withdrawal of lithium therapy. Diabetes Care 2006, 29:1181.

167. Macko AR, Beneze AN, Teachey MK, Henriksen EJ: Roles of insulin signalling and $\mathrm{p} 38$ MAPK in the activation by lithium of glucose transport in insulin-resistant rat skeletal muscle. Arch Physiol Biochem 2008, 114:331-339

168. Harrell NB, Teachey MK, Gifford NJ, Henriksen EJ: Essential role of p38 MAPK for activation of skeletal muscle glucose transport by lithium. Arch Physiol Biochem 2007, 113:221-227.

169. Hermida OG, Fontela $T$, Ghiglione M, Uttenthal LO: Effect of lithium on plasma glucose, insulin and glucagon in normal and streptozotocindiabetic rats: role of glucagon in the hyperglycaemic response. $\mathrm{Br} J$ Pharmacol 1994, 111:861-865.

170. Rodriguez-Gil JE, Fernandez-Novell JM, Barbera A, Guinovart JJ: Lithium's effects on rat liver glucose metabolism in vivo. Arch Biochem Biophys 2000, 375:377-384

171. Bartlett HE, Eperjesi F: Nutritional supplementation for type 2 diabetes: a systematic review. Ophthalmic Physiol Opt 2008, 28:503-523.

172. Chang Y, Zhang GZ, Piao SL, Gao S, Zheng DM, Song Y, et al: Protective effects of combined micronutrients on islet beta-cells of streptozotocininduced diabetic mice. Int J Vitam Nutr Res 2009, 79:104-116.

173. Faure $P$, Barclay D, Joyeux-Faure M, Halimi S: Comparison of the effects of zinc alone and zinc associated with selenium and vitamin $E$ on insulin sensitivity and oxidative stress in high-fructose-fed rats. J Trace Elem Med Biol 2007, 21:113-119.

174. Padmavathi IJ, Rao KR, Venu L, Ganeshan M, Kumar KA, Rao Ch N, et al: Chronic maternal dietary chromium restriction modulates visceral adiposity: probable underlying mechanisms. Diabetes 2010, 59:98-104.

175. Padmavathi IJ, Rao KR, Venu L, Ismail A, Raghunath M: Maternal dietary chromium restriction programs muscle development and function in the rat offspring. Exp Biol Med 2010, 235:349-355.

176. Venu L, Harishankar N, Krishna TP, Raghunath M: Does maternal dietary mineral restriction per se predispose the offspring to insulin resistance? Eur J Endocrinol 2004, 151:287-294.

doi:10.1186/1758-5996-2-70

Cite this article as: Wiernsperger and Rapin: Trace elements in glucometabolic disorders: an update. Diabetology \& Metabolic Syndrome 2010 2:70. 